\title{
Rekonstruksi Perabot Rumah Tangga Berdasarkan Relief Karmawibhangga Candi Borobudur
}

\author{
Rahmanu Widayat $^{1 *}$, Anung B. Studyanto \\ ${ }^{1,2}$ Program Studi Desain Interior, Fakultas Seni Rupa dan Desain, \\ Universitas Sebelas Maret, Surakarta, Indonesia \\ rahmanuwidayat@staff.uns.ac.id ${ }^{1^{*}}$,anungbs@staff.uns.ac.id ${ }^{2}$
}

\begin{abstract}
Abstrak. Perkembangan perabot rumah tangga saat ini mengalami perkembangan yang pesat, namun warisan perabot rumah tangga zaman dahulu masih ada yang tetap bertahan. Menarik mengetahui perabot rumah tangga pada abad ke-9 melalui relief Karmawibhangga Candi Borobudur yang berbentuk dua dimensi. Lebih menarik lagi membuat replika perabot rumah tangga ini sehingga dapat diketahui bentuk tiga dimensinya. Persoalannya adalah apa saja dan bagaimana bentuk perabot rumah tangga yang terdapat pada relief Candi Borobudur. Selanjutnya apa saja manfaat menelaah perabot rumah tangga pada relief Candi Borobudur. Metode yang digunakan adalah mengidentifikasi, merekonstruksi, dan menarik nilai manfaatnya. Hasilnya beberapa jenis perabot rumah tangga dan beberapa replika. Nilai manfaatnya sebagai sumber inspirasi pengembangan desain perabot rumah tangga masa kini dan turut menghargai dan mengembangkan warisan tanpa surat wasiat dari nenek moyang.
\end{abstract}

Kata Kunci: rekonstruksi, perabot rumah tangga, relief Candi Borobudur

\section{Reconstruction of Household Furniture Based on the Karmawibhangga Relief of Borobudur Temple}

The development of modern household furniture is currently experiencing rapid expansion. On the other hand, the legacy of ancient household furniture still survives; it can be seen from household furniture in the 9th century through the two-dimensional Karmawibhangga reliefs of Borobudur Temple. To understand the three-dimensional shape from the relief, it is interesting to make a replica of this household furniture. The problem of this study is to understand the form of household furniture found in the reliefs of Borobudur Temple. The method used in this study is identification, reconstruction, and analyzation the value of its benefits. The result is several types of household furniture replicas. The benefits of this study are as a source of inspiration for the development of modern home furniture designs and also to respect and develop the legacy from the ancestors.

Received: November 2, 2021; Accepted January 27, 2022; Published February 7, 2022 https://doi.org/10.31091/mudra.v37i1.1893

(C) 2021 The Author(s). Published by Pusat Penerbitan LP2MPP Institut Seni Indonesia Denpasar. This is an open-access article under the CC BY-NC-SA license 


\section{PENDAHULUAN}

Relief Candi Borobudur menyimpan ilmu pengetahuan yang luar biasa (Cahyandaru, 2013), terutama untuk pendukung kehidupan abad ke-9 masyarakat di Jawa, dan yang hidup saat ini ketika mau menggali potensi Candi Borobudur. Dari beberapa jenis relief yang menarik terkait kehidupan saat itu adalah relief Karmawibhangga yang dipahatkan pada kaki candi. Struktur secara vertikal bangunan candi mempunyai kaki, badan, dan kepala (Yatno, 2020). Kaki Candi Borobudur lambang Kamadhatu atau dunia manusia yang terikat nafsu. Tubuh candi lambang Rupadhatu yaitu dunia manusia yang mampu mengendalikan nafsu namun masih terikat oleh bentuk. Kepala candi melambangkan Arupadhatu, yakni dunia dewa yang tak terikat bentuk maupun nafsu. Kamadhatu, Rupadhatu, dan Arupadhatu gambaran perjalanan spiritual makhluk hidup mendapatkan pencerahan, kesempurnaan, dan kesucian bebas reikarnasi dan menuju nirwana (Nugraheni, 2012). Relief Karmawibhangga dapat dikatakan pencerminan kehidupan sehari-hari masyarakat waktu itu dilihat dari para pemahat, pembuat arca, dan arsitekturnya atau disebut silpin yang tahu banyak kehidupan sehari-hari di Jawa dan menginspirasi dalam menerjemahkan teks Karmawibhangga dalam relief (Santiko, 2016). Karmawibhangga berisi ajaran perihal sebab dan akibat perbuatan baik dan jahat (Marzuki dan Heraty, 1993), sehingga menarik ketika digali perabot rumah tangga penunjang kehidupan waktu itu.

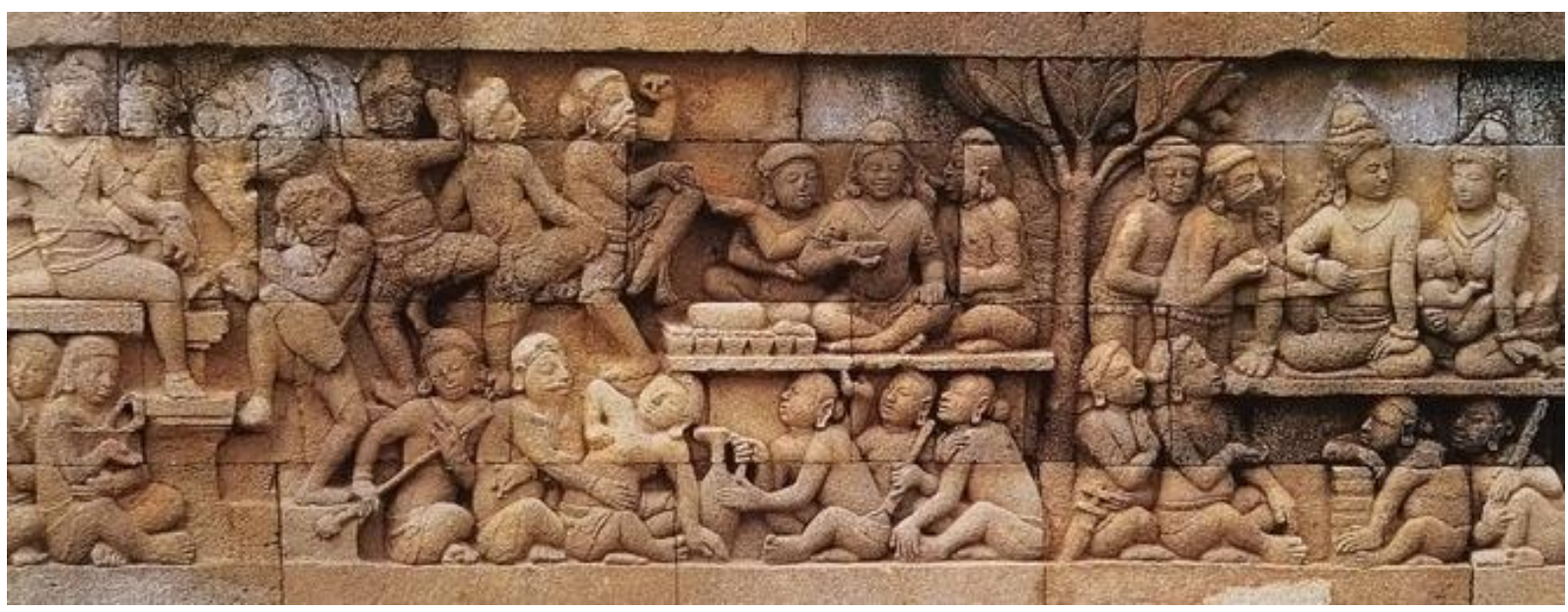

Gambar 1. Panil 20, memperlihatkan perbedaan mencolok antara keluarga bahagia sisi kanan relief dan pemabuk sisi kiri relief. Akibat lupa diri, pemabuk itu melakukan kenistaan yang terlarang, seperti perbuatan mesum dan menari-nari tak beraturan (Sumber: Foto buku "Borobudur Golden Tales of the Buddhas", halaman 67)

Perabot rumah tangga adalah barang-barang perlengkapan untuk kepentingan rumah tangga. Pengertian perabot sama dengan furniture dalam bahasa Inggris dan mebel yang berasal dari bahasa Belanda yakni meuble. Terkait furniture atau mebel di dalamnya terdapat empat jenis kepentingan yaitu 1) tempat menyimpan sesuatu di dalamnya, 2) tempat menaruh sesuatu di atasnya, 3) tempat tidur, 4) tempat duduk (Jamaludin, 2007). Ketika perabot adalah sama dengan perlengkapan maka tidak sekedar furniture ataupun mebel namun pengertiannya lebih luas, apalagi dikaitkan dengan rumah tangga. Rumah tangga adalah seseorang atau sekelompok yang tinggal pada sebagian atau seluruh bangunan yang kebutuhan sehari-harinya diurus menjadi satu (Badan Pusat Statistik, 2021).

Perabot rumah tangga memiliki jenis yang bervariasi sesuai dengan kebutuhan rumah tangga dalam struktur masyarakatnya. Seperti kehidupan zaman sekarang perlengkapan rumah tangga yang dibutuhkan tentu berbeda-beda tergantung apakah itu rumah tangga golongan atas, golongan menengah, dan golongan bawah, atau golongan kelas tinggi, kelas sedang, dan kelas rendah (Maunah, 2015). Hal ini diketahui berdasarkan penghasilan yang didapatkan. Kehidupan sezaman dengan Candi Borobudur, banyak profesi dari masyarakat kebanyakan dalam mendukung kehidupan waktu itu. Berdasarkan relief Karmawibhangga Candi Borobudur dan sejumlah prasasti sezaman tidak kurang 100 (seratus) jenis profesi yang dijalani masyarakat (Nugrahani, 2012). Perabotan rumah tangga pada relief Candi Borobudur belum cukup menarik bagi kalangan peneliti. Penulis dan tim pada tahun 2015 dan 2016 telah melakukan penelitian tentang rekonstruksi Kursi Borobudur. Kursi dan fasiltas duduk lainnya kami rekonstruksi dan dibuat replikanya. Pada tahun 2017 replika Kursi Borobudur kami kembangkan bedasarkan konsep estetika aèng atau aneh menghasilkan prototype kursi yang unik (Widayat dan Studyanto, 2017). Aèng adalah konsep estetika di luar alam pikiran orang Jawa yang indah atau 
wangun, namun diakui keberadaannya dan dapat diterima oleh orang Jawa (Widayat, 2016). Selain itu pada tahun 2019 dan 2020 kami mencoba mengembangkan desainnya dan menghasilkan prototype untuk kepentingan masyarakat sekarang. Baik itu untuk kepentingan industri furniture yang siap hilirisasi, maupun yang lebih khusus dikembangkan sebagai media ekspresi menjadi karya seni atau art chair (Widayat, 2021).

Saat ini penulis dan tim mencoba menggali perabotan rumah tangga berdasarkan relief Candi Borobudur yang belum menjadi minat peneliti lain. Candi Borobudur banyak dikagumi orang, baik dari dalam dan luar negeri. Sebagai negara, Indonesia boleh dikatakan muda, namun mempunyai masa lalu yang cukup tua, panjang dan gemilang, bernenek moyang terampil dan berbudi tinggi. Candi Borobudur sebagai karya seni-budaya yang membanggakan dikagumi bangsa lain yang terpelajar dan beradap (Joesoef, 2004). Raffles yang dianggap penemu kembali Candi Borobudur tahun 1814 mengatakan Candi Borobudur merupakan karya yang agung, bentuknya yang simetri, teratur, relief dan ornamen mempunyai karakter yang menarik (2008). Candi, arca, relief dibuat oleh para silpin berdasarkan kitap manara silpasastra. Para silpin dari kalangan brahmana yang paham mantra sebelum membuat sesuatu (BPCB Jawa Tengah, 2019). Sebenarnya di balik keagungan dan keindahannya Candi Borobudur yang dibuat oleh para silpin, masih menyimpan banyak misteri untuk dikaji. Penelitian ini sangat bermanfaat untuk mengetahui jenis perabot rumah tangga yang digunakan waktu itu sekitar abad ke-9 atau semasa dengan didirikannya Candi Borobudur sekitar tahun 800 Masehi (Santiko, 2012). Seperti apa bentuknya dan apakah benda-benda yang digunakan seribu dua ratus tahun yang lalu itu masih ditemukan dalam kehidupan zaman sekarang abad ke-21. Setelah mengetahui jenis dan bentuknya pertanyaannya adalah apakah ada manfaatnya mempelajari perabotan rumah tangga masa lalu itu atau digunakan untuk apa. Kegelisahan-kegelisahan ini dapat dirumuskan dalam pertanyaan penelitian sebagai berikut. 1) Perabot rumah tangga apa saja yang terdapat pada relief Candi Borobudur? 2) Bagaimana bentuk perabot rumah tangganya? 3) Apa manfaat dari perabot rumah tangga pada relief Candi Borobudur?

\section{LITERATUR DAN TEORI}

Literatur dalam artikel ini berhubungan dengan perabot rumah tangga dan relief Candi Borobudur. Teori yang digunakan berhubungan dengan konsep rekonstruksi. Perabot rumah tangga adalah barangbarang perlengkapan rumah tangga seperti meja, kursi dan sebagainya. Rumah tangga abad ke-9 di Jawa tentu berbeda dengan rumah tangga zaman sekarang. Rumah tangga waktu itu berdasarkan struktur sosial yang berlaku pada zaman tersebut. Terdapat tiga kelas dalam masyarakat yaitu 1) Tiga golongan rohaniawan (pendeta, bhiksu, resi); 2) Penguasa (cakrawartin/raja, bangsawan, kepala desa, tuan tanah) 3) Masyarakat kebanyakan (petani, pedagang, pemain musik, penari, pemain akrobat, pengamen, tabib, algojo, dukun beranak, dan pelayan) (Nugrahani, 2012). Berdasarkan struktur masyarakat pada waktu itu perabot rumah tangga yang dimiliki pada abad ke-9 juga berbeda. Selain perbedaan ada juga perabotan yang digunakan oleh seluruh lapisan masyarakat.

\section{DATA DAN METODE}

Data-data diidentifikasi berdasarkan perabot rumah tangga pada relief Karmawibhangga Candi Borobudur. Sumber relief dari foto-foto Tropenmuseum berdasarkan karya Kassian Chepas saat mendokumentasi relief tahun 1890 - 1891 . Relief yang diamati adalah yang dapat menunjukan strata masyarakat waktu itu. Metode rekonstruksi berdasarkan data yang ada diinterpretasi dalam konteks bahan, dimensi, dan budaya. Kemudian dibuat sketsa perspektif, gambar kerja, dan replika skala $1: 1$. Untuk pembuatan replika dipilih perabot yang dalam kehidupan saat ini jarang ditemukan, jika adapun bentuknya sudah berbeda.

\section{HASIL DAN PEMBAHASAN}

Relief Karmawibhangga mempunyai 160 panil, berdasarkan struktur sosial dapat diidentifikasi panil-panil tiga jenis golongan yang terdapat dalam masyarakat (Nugrahani, 2012). Hal ini dijadikan pedoman awal mengingat sebenarnya perabot rumah tangga banyak tersebar pada penil-panil yang lainnya. Ukuran tiap-tiap panil tinggi 67 centimeter dan panjang dua meter ditemukan tertutup selasar batu secara tidak sengaja tahun 1885 , oleh J.W. Ijzerman penutup dibuka dan setelah selesai didokumentasi melalui foto tahun $1890-1891$ ditutup kembali (Miksic, 1996; Hariani, 2012). Sesungguhnya tidak semuanya dikembalikan seperti semula, namun disisakan tiga buah panil di sudut tenggara agar dapat dilihat. Berdasarkan panil-panil 
yang telah didokumentasi tersebut dapat diketahui jenis-jenis perabot rumah tangga yang ada.

\section{Jenis Perabot Rumah Tangga}

\section{Golongan Rohaniawan}

Golongan rohaniawan yang bertugas memberikan pengajaran tentang agama dan pengetahuan dari kitab, terdapat pada panil 60. Pada panil 55 terdapat perabot berupa fasilitas duduk, tempat buah, dan kendi, sedangkan panil 60 tidak terdapat perabot rumah tangga. Adegan saat memberi wejangan terdapat pada panil 46 relief dalam keadaan rusak. Adegan memberi wejangan pada panil 49 tidak ditemukan perabobot rumah tangga. Golongan Rohaniawan menerima persembahan baik dari penguasa maupan masyarakat kebanyakaan dalam bentuk bunga yaitu pada panil 7 terdapat fasilitas duduk, sedangkan pada panil 31 terdapat tokoh bhiksu, namun tidak terdapat perabot rumah tangga.

\section{Golongan Penguasa}

Golongan penguasa mempunyai sumber daya berupa kekuasaan dan harta benda, tugasnya memberi derma dan sedekah kepada golongan rohaniawan terdapat pada panil 12 , terdapat perabot rumah tangga berupa kendi. Adegan derma dan sedekah kepada golongan fakir miskin pada panil 32 , sedangkan perabotan yang dapat diidentifikasi berupa fasilitas duduk bantalan kasur, fasilitas duduk panjang, wadah, kendi, dan tempat penyimpanan. Pada Panil 67 terdapat wadah, dan tempat penyimpanan. Derma dan sedekah berupa bahan makanan, pakaian, uang terlihat pada panil 107, pada relief terdapat perabotan semacama genthong atau tempat air gerabah.

\section{Masyarakat Kebanyakan}

Berbagai profesi masyarakat kebanyakan di antaranya petani terdapat pada panil 65 tidak ada perabotan; pedagang panil 1 berupa pikulan; pemain musik panil 39 tidak ada perabotan; adegan menari pada panil 72 ditafsirkan berupa alat musik kendang, dan tidak ada perabot rumah tangga. Profesi sebagai pemain akrobat panil 52 tidak ada perabotan; pengemis dan pengamen panil 117 tidak ada perabotan. Tabib panil 18 terdapat benda berwujud genthong dan wadah air dari gerabah. Algojo pada panil 4 terdapat pedang; dukun beranak pada panil 3 tidak ditemukan perabotan; dan pelayan pada panil 18 , perabotan rumah tangganya sama dengan tabib.

\section{Rekonstruksi dan Replika Perabot Rumah Tangga}

Rekonstruksi dilakukan dengan identifikasi interpretasi perabot pada relief, kemudian dibuat sketsa perspektif dilengkapi keterangan dimensi dan bahan. Untuk menentukan dimensi berdasarkan tinggi manusia Jawa pada abad ke-9, mengingat sulitnya sumber data hal ini memerlukan perbandingan dengan tinggi rata-rata manusia Asia Tenggara saat ini yakni $160 \mathrm{~cm}$, digunakan sebagai acuan (Putri, 2019). Sebenarnya untuk menentukan dimensi yang terdapat pada relief ada yang tidak sesuai dengan skala manusia, mengingat besarnya panil terbatas sehingga untuk penggambaran pada relief harus dikecilkan, contohnya seperti penggambaran candi, rumah, dan pohon. Sedangkan untuk perabot rumah tangga masih menyesuaikan dengan dimensi manusia. Saat membuat replika atau tiruan perabotan setelah proses rekonstruksi, penggunaan bahan tidak harus sama dengan bahan aslinya pada waktu itu, namun lebih ditekankan pada bentuk diusahakan semirip mungkin. Rekonstruksi adalah mengembalikan suatu tempat dalam hal ini benda perabot rumah tangga semirip mungkin dengan keadaan semula, dengan menggunakan bahan lama maupun bahan baru (Sidharta dan Budihardjo, 1989). Replika perabot rumah tangga tidak dibuat semua namun dipilih dengan alasan tertentu. Alasan ini di antaranya perabot rumah tangga fasilitas duduk sudah dibuat replika oleh penulis dan kawan-kawan pada riset sebelumnya. Perabotan lain seperti genthong, kendi, wadah, pikulan, pedang tidak dibuat replikanya, karena bentuk benda-benda tersebut masih mirip dengan yang digunakan saat ini dan bentuknya belum banyak berubah. Menarik untuk dibuat replikanya adalah tempat penyimpanan berupa peti dengan variasi bentuk cukup banyak. Peti yang terdapat pada relief Candi Borobudur inilah yang sudah tidak ditemui saat ini, sehingga penting untuk dibuat replikanya dan menarik ketika ditunjukkan ke kalangan luas dengan nama "Peti Borobudur". Proses rekonstruksi perabot rumah tangga seperti berikut.

\section{Perabot Rumah Tangga Golongan Rohaniawan}

Golongan rohaniawan tidak hanya dari Buddha, namun yang dipahatkan pada relief terdiri dari 18 bhiksu (Buddha), 29 pendeta Siwa (Hindhu), dan rsi belum teridentifikasi jumlahnya (Santiko, 2015). Ciri-ciri bhiksu berkepala gundul, mengenakan jubah dengan pundak kanan terbuka, memegang tempurung untuk menampung sumbangan, kadangkadang membawa tongkat maupun tasbih. Ciri pendeta Siwa memakai jato-makuta atau mahkota rambut dan upawita atau tali kasta. Sramana penyebutan pertapa dalam buddha dan rsi penyebutan pertapa dalam Buddha dan Hindu (Krismono, 2020). Fasiltas duduk, dan kendi gerabah, perabot rumah tangga ini terdapat pada 
panil 55, dan 7. Pada panil 55 sisi kiri perabotan dapat diidentifikasi sebagai fasiltas duduk, dilihat dari bentuknya ditafsirkan bahannya terbuat dari kayu. Fasilitas duduk ini sudah penulis buat replikanya pada tahun 2015 (Widayat dan Studyanto, 2015) (lihat kelompok Gambar 2). Perabot lain berupa wadah ada di bawahnya kursi, bahan belum dapat diidentifikasi dan isi wadah juga belum diketahui. Pada adegan sisi kanan relief terdapat fasilitas duduk dari kayu yang diduduki oleh tiga orang bhiksu atau pendeta Buddha berhadapan dengan murid-muridnya. Perabot rumah tangga kendi terlihat bawah fasilitas duduk bhiksu. Adegan di tengah adalah pertapa yang sedang berjalan memakai payung.

Relief panil 7 berupa adegan golongan rohaniawan yang sedang berbincang-bincang duduk di atas fasilitas duduk. Bahan fasiltas duduk ini belum dapat diidentifikasi kemungkinan dari bahan kayu atau bahkan dari batu, dan dicoba direkonstruksi dengan sketsa perspektif untuk melihat gambar secara tiga dimensi.
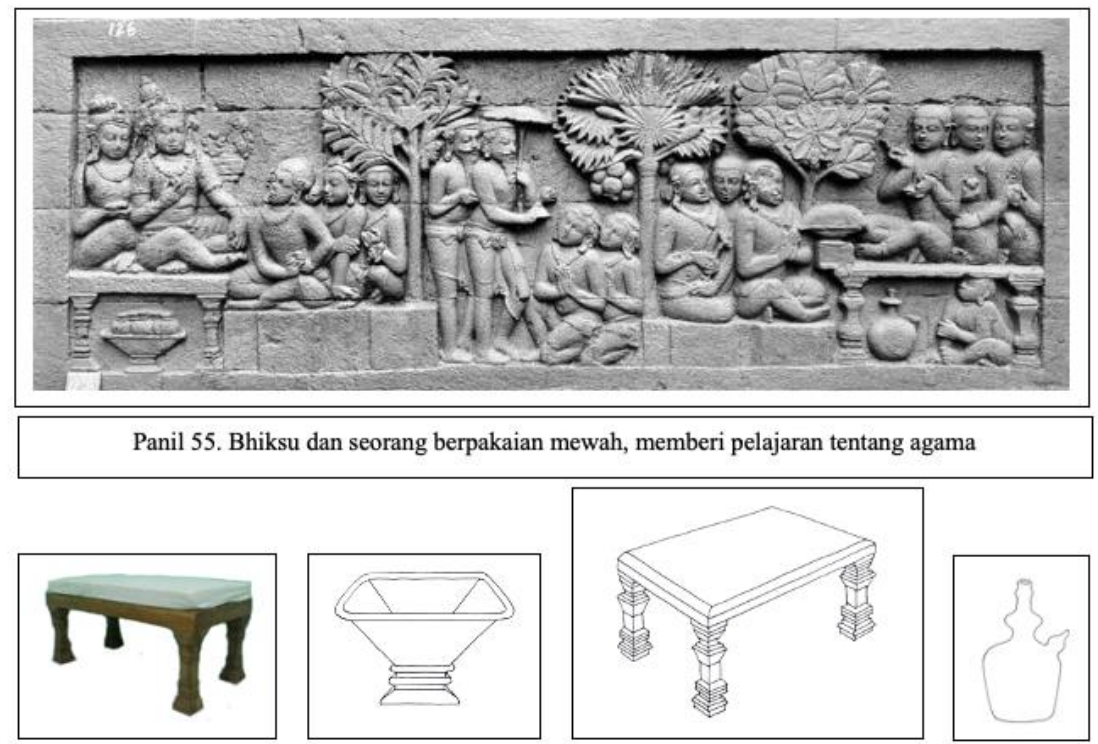

Gambar 2. Panil 55 (sumber: Tropenmuseum), teks panil dikutip dari buku “Adegan dan Ajaran Hukum Karma pada Relief Karmawibhangga"terdapat perabot rumah tangga antara lain: fasilitas duduk sudah dibuat replikanya tahun 2015, tempat buah, fasilitas duduk dan kendi (tempat air minum) (sumber: foto dan sketsa penulis)

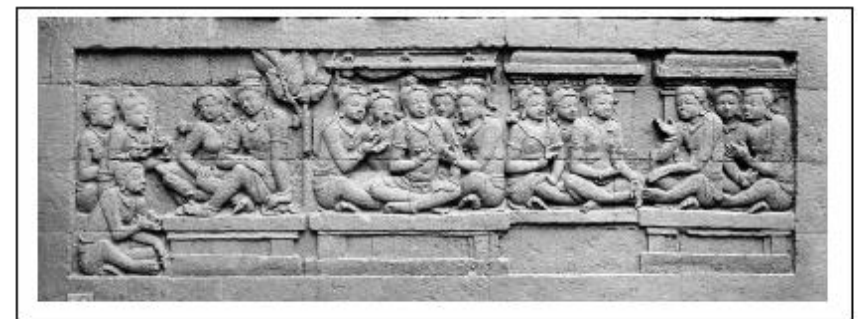

Panil 7. Berbincang-bincang dan persembahan bunga

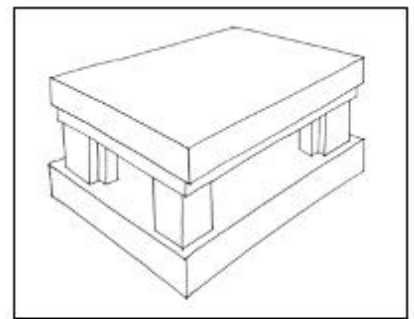

Fasilitas duduk

Gambar 3. Panil 7, (sumber: Tropenmuseum), teks panil dikutip dari buku "Adegan dan Ajaran Hukum Karma pada Relief Karmawibhangga", terdapat perabot rumah tangga berupa fasilitas duduk (sumber: sketsa penulis)

\section{Perabot Rumah Tangga Golongan Penguasa}

Fasilitas duduk, bantalan atau kasur, tempat penyimpanan (peti), wadah, kendi gerabah, dan genthong gerabah. Perabot rumah tangga berupa peti ini menjadi penciri golongan penguasa. Peti-peti dan perabotan diletakkan di bawah fasilitas duduk, makin banyak perabotan yang ada makin kaya golongan penguasa tersebut. Perabotan tersebut terdapat pada panil 12, 32, dan 107. Perabot rumah tangga yang sudah dapat diidentifikasi bahannya seperti kendi tempat air minum dan genthong dari gerabah atau dari bahan tanah liat yang dibakar, fasilitas duduk dari kayu, beberapa peti terbuat dari kayu atau bahan lain yang belum diketahui. Relief panil 12 terdapat fasiltas duduk sudah dibuat sketsa perspektifnya dapat diperkirakan bahan terbuat dari kayu dan dilengkapi dengan bantalan atau kasur. Adegan sebelah kanan terdapat perabot rumah tangga berupa kendi dan semacam mangkok tempat untuk minum. Relief panil 32 dapat diidentifikasi perabot rumah tangga berupa bantalan kasur, wadah, 
fasilitas duduk dari bahan kayu, di bawahnya terdapat kendi gerabah tempat air minum, dan tempat penyimpanan seperti peti yang dari sisi bahan belum dapat diidentifikasi secara pasti. Pada panil 107, adegan di sebelah kiri terdapat fasilitas duduk yang sedang diduduki dan sulit direkonstruksi karena tertutup relief manusia, sedangkan di bawahnya terdapat enam buah genthong, adegan di tengah terdapat tiga buah genthong.
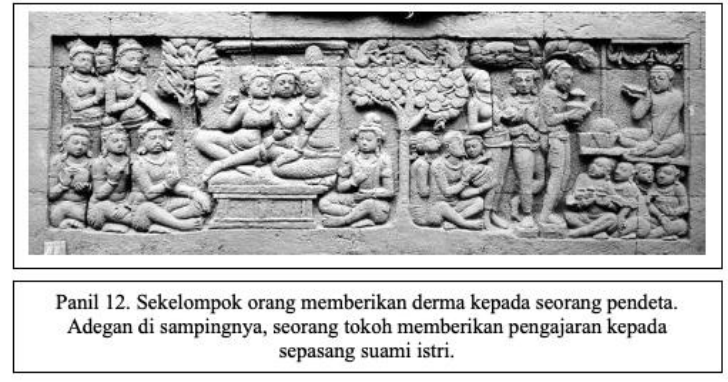

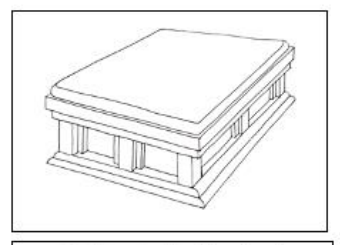

Fasilitas duduk dilengkapi bantalan kasur

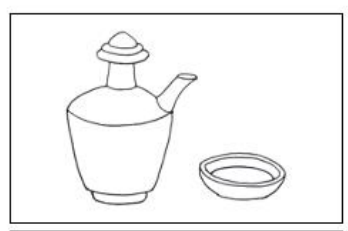

Kendi dan mangkok untuk minum

Gambar 4. Panil 12 (sumber: Tropenmuseum), teks panil dikutip dari buku "Adegan dan Ajaran Hukum Karma pada Relief Karmawibhangga", terdapat perabot rumah tangga berupa fasilitas duduk, kendi, mangkok untuk minum, dan beberapa wadah yang belum teridentifikasi (sumber: sketsa penulis)
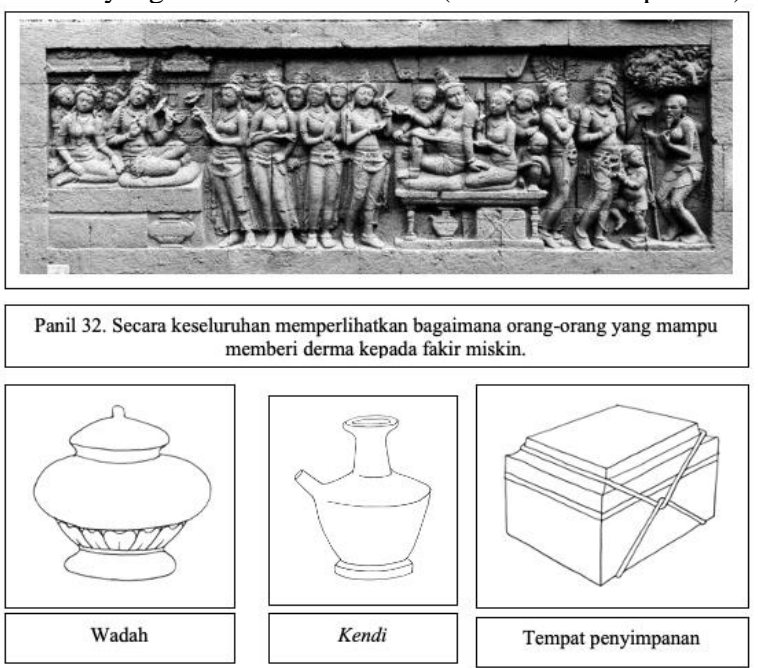

Gambar 5. Panil 32 (sumber: Tropenmuseum) teks panil dikutip dari buku "Adegan dan Ajaran Hukum Karma pada Relief Karmawibhangga", terdapat perabot wadah, kendi, dan tempat penyimpanan (sumber: sketsa penulis)

\begin{tabular}{|l|}
\hline Panil 107. \\
Pemberian \\
hadiah \\
kepada \\
pelayan \\
\end{tabular}
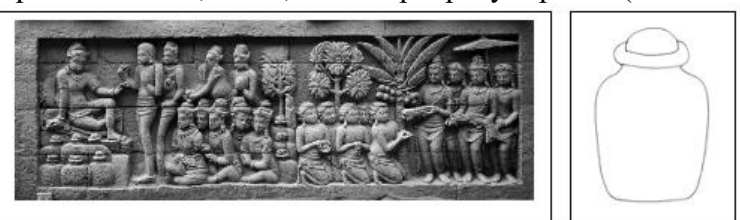

Gambar 6. Panil 32 (sumber: Tropenmuseum) teks panil dikutip dari buku "Adegan dan Ajaran Hukum Karma pada Relief Karmawibhangga", terdapat perabot genthong dari gerabah (sumber: sketsa penulis) 


\section{Perabot Rumah Tangga Masyarakat Kebanyakan}

Perabotan untuk masyarakat kebanyakan lebih ditampilkan berdasarkan profesi masyarakat kala itu, yaitu berupa pikulan, kendang, genthong, wadah, pedang dan lain-lain. Terkait bahan ada yang sudah dapat diidentifikasi seperti genthong dari gerabah, pedang dari bahan metal, pikulan dari kayu atau bambu, dan ada juga yang belum teridentifikasi. Relief panil 1 terdapat perabot pikulan yang digunakan sebagai sarana untuk membawa barang dagangan di pasar. Relief panil 2 terdapat perabotan dapur zaman dahulu yaitu tempat api untuk memasak atau tungku dan semprong kemungkinan terbuat dari bambu untuk membesarkan api dengan jalan ditiup. Terdapat juga kwuali dari gerabah, yaitu tempat merebus semacam panci saat ini. Relief panil 72 yang menggambarkan adegan tari-tarian, adegan di tengah relief berdasarkan gestur tubuh seperti membunyikan sesuatu dengan tangan dapat diidentifikasi benda tersebut sebagai kendang. Pada relief 18 terdapat beberapa perabot genthong dan susunan wadah yang fungsinya belum diketahui. Relief panil 4 terlihat perabotan dua buah pedang. Perabot rumah tangga masyakat kebanyakan dapat dilihat pada gambar berikut.

\begin{tabular}{|l|}
\hline Panil 1. Orang menangkap \\
ikan dan menjualnya ke \\
pasar. Di pasar, seorang \\
penabuh genderang sedang \\
berteriak mengumumkan \\
sesuatu
\end{tabular}

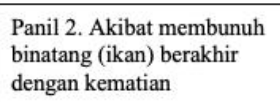

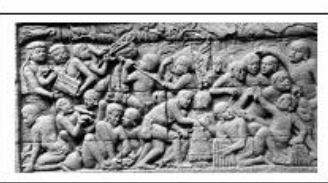

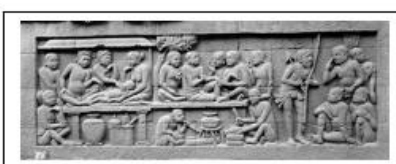

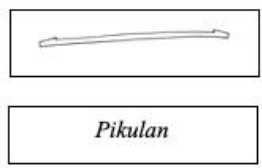

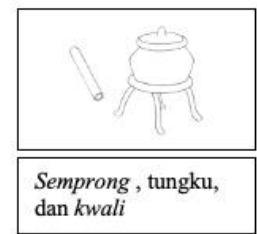

Panil 4. Dua algojo
menghukum seorang dengan
dijerat lehernya
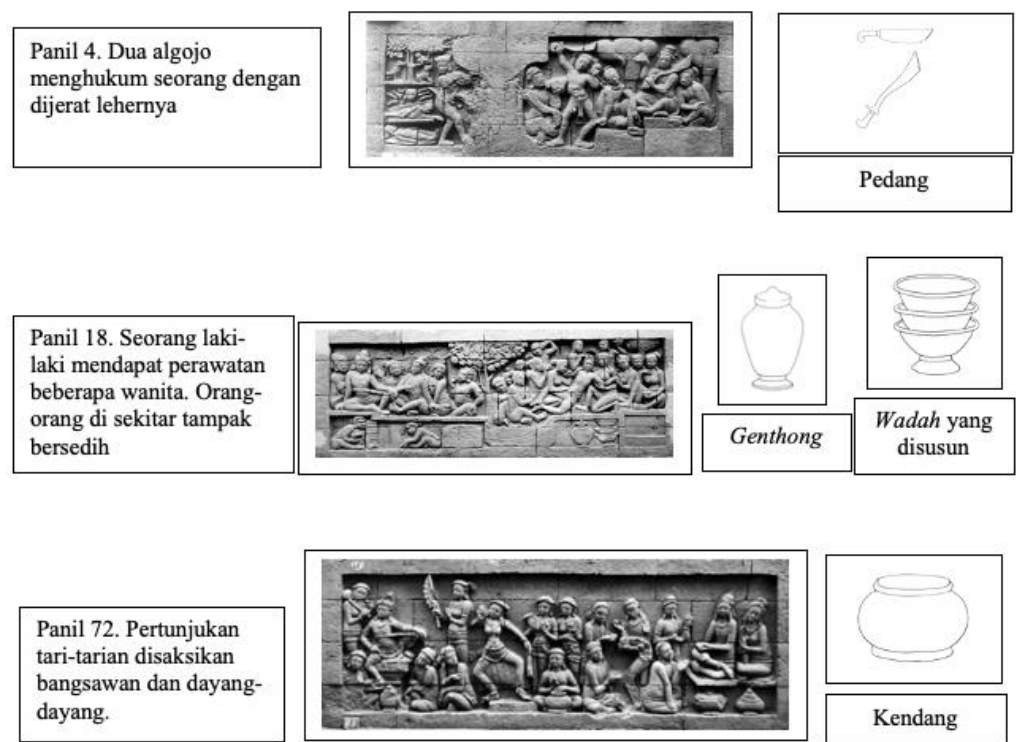

Gambar 7. Panil 1,2,4,18, 72 (sumber: Tropenmuseum), teks panil dikutip dari buku "Adegan dan Ajaran Hukum Karma pada Relief Karmawibhangga" dan sketsa rekonstruksi pikulan, semprong, tungku, kwali, pedang, genthong, wadah, dan kendang (sumber: sketsa penulis) 


\section{Temuan Tempat Penyimpanan}

Temuan menarik perabot rumah tangga adalah tempat penyimpanan. Berdasarkan relief Karmawibhangga tidak kurang dari 35 buah tempat penyimpanan. Menarik karena beberapa peti menyerupai tempat harta karun. Interpretasi sementara tempat penyimpanan digunakan untuk menyimpan banyak benda seperti busana dan aksesorisnya, kain, perhiasan, kemungkinan juga untuk menyimpan bahan makanan padi atau beras, dan sebagainya. Tempat penyimpanan yang direkonstruksi tidak sejumlah yang ada pada relief karena ada yang mempunyai persamaan bentuk. Beberapa bentuk tempat penyimpanan seperti gambar berikut ini.

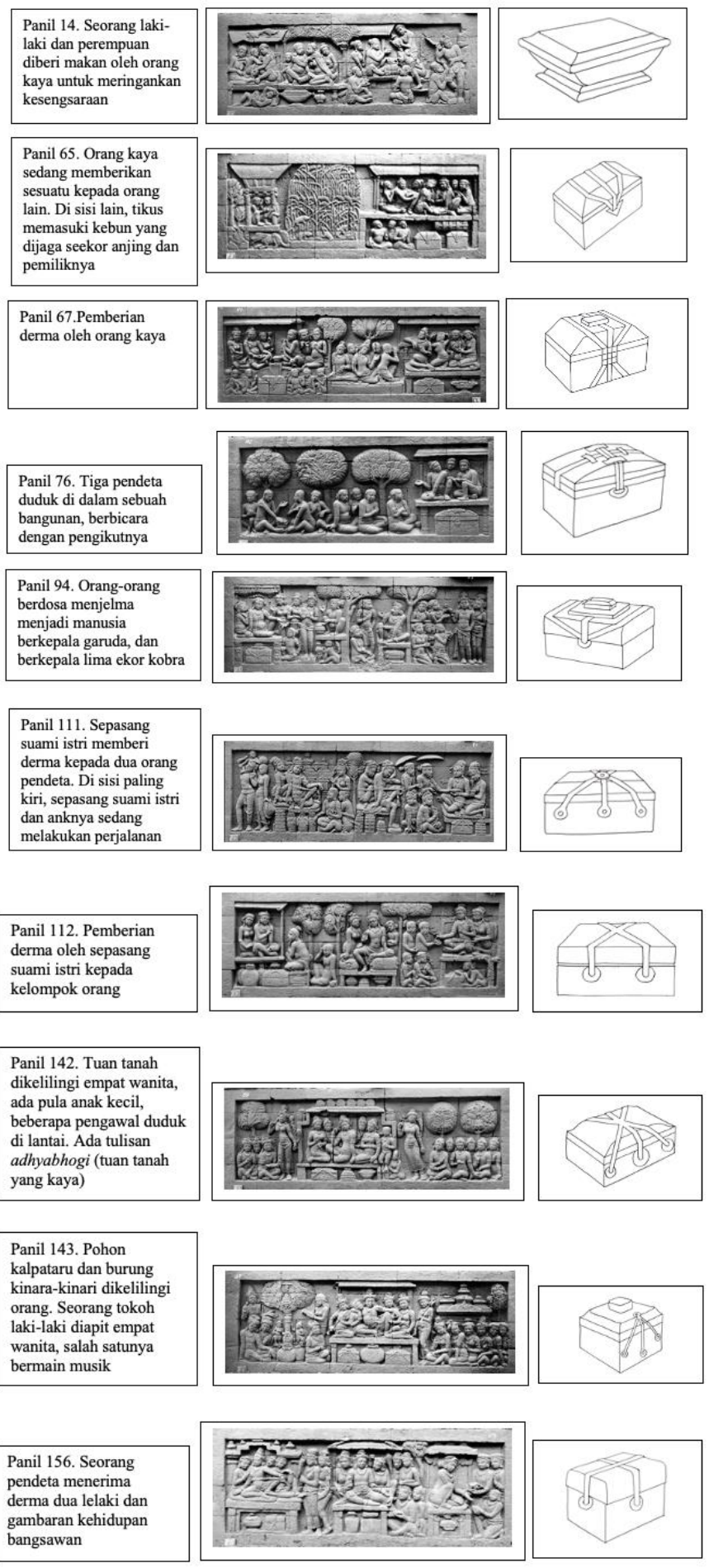

Gambar 8. Panil 14, 65, 67, 76, 94, 111, 112, 142, 143, 156 (sumber: Tropenmuseum), teks panil dikutip dari buku "Adegan dan Ajaran Hukum Karma pada Relief Karmawibhangga” dan sketsa rekonstruksi tempat penyimpanan (sumber: penulis) 


\section{Pembuatan Replika}

Untuk pembuatan replika perabot rumah tangga dipilih tiga buah peti tempat penyimpanan dinamakan "Peti Borobudur", berdasarkan panil 32, 112, dan panil 156. Dimensi berdasarkan tinggi ratarata manusia Indonesia, bahan ditafsirkan dari kayu.

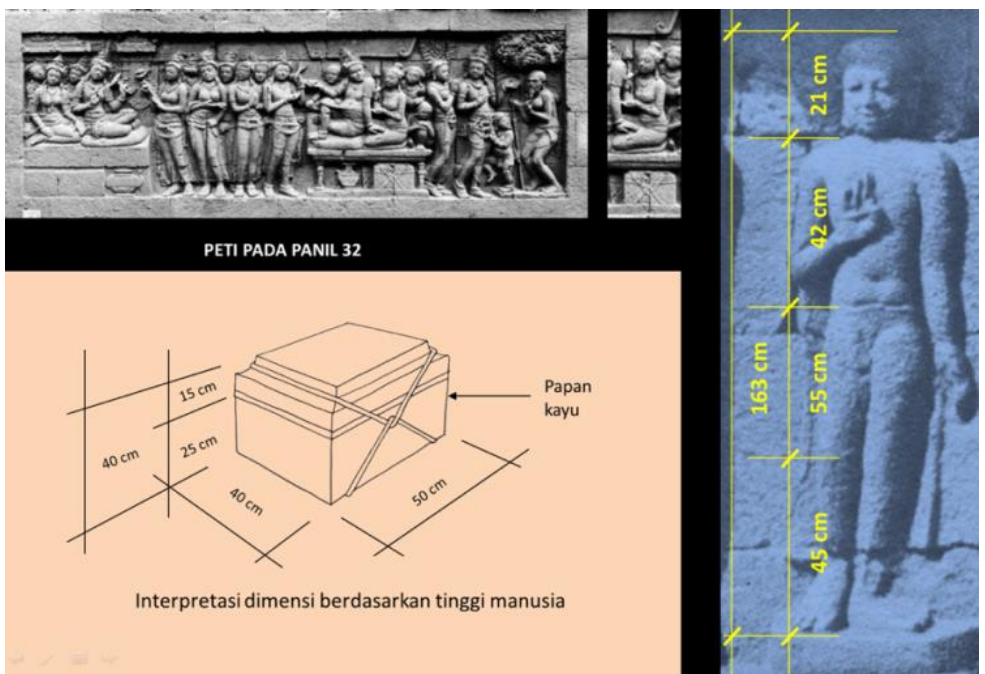

Gambar 9. Tempat Penyimpanan (Peti Borobudur 1) yang dibuat replikanya

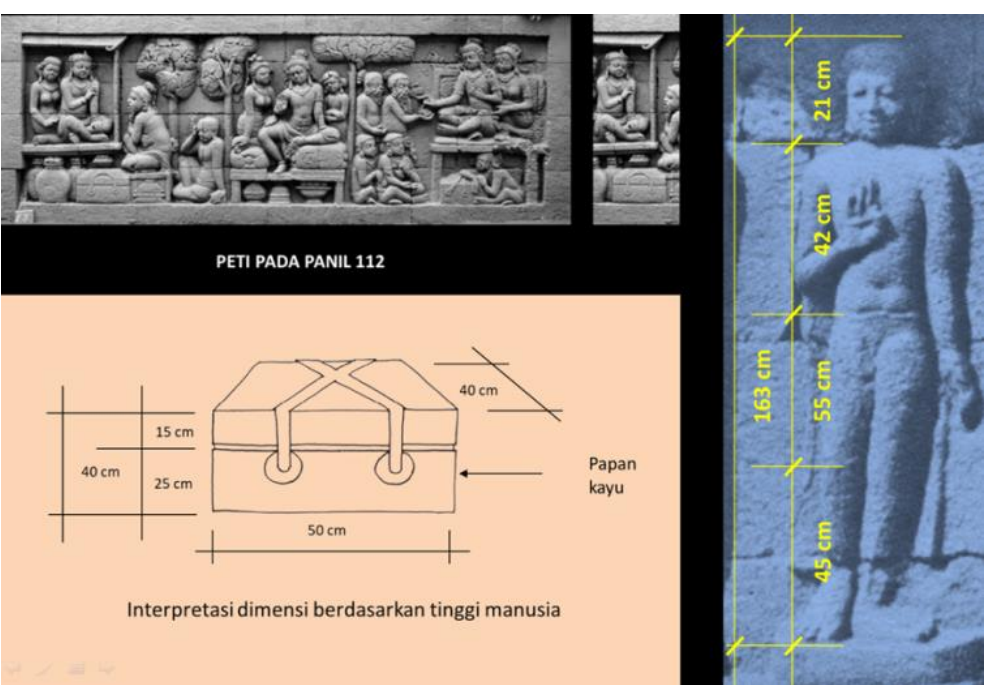

Gambar 10. Tempat Penyimpanan (Peti Borobudur 2) yang dibuat replikanya

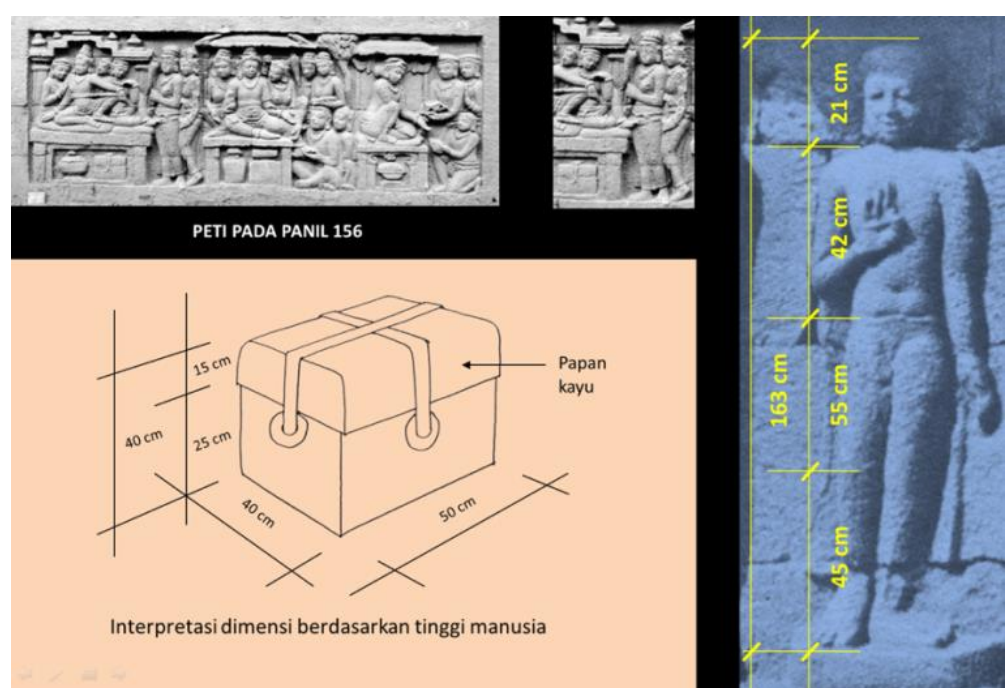

Gambar 10. Tempat Penyimpanan (Peti Borobudur 3) yang dibuat replikanya 


\section{Manfaat Perabot Rumah Tangga}

Pengisi museum berupa replika perabot rumah tangga yang dapat dilihat pengunjung dan dapat digunakan sebagai obyek studi. Pengisi galeri, artshop, ruang pamer yang lain untuk kepentingan ekonomis dan dapat dibeli oleh para peminat. Sebagai koleksi pribadi para kolektor yang meminati perabot rumah tangga kuno dalam bentuk replika. Contoh replika perabot rumah tangga kuno adalah kursi singgasana Tuntankhamun Zaman Mesir Kuno yang banyak direplika untuk berbagai kepentingan zaman sekarang (King Tut Replica Throne Chair, 2021).

Sebagai sumber ide untuk dikembangkan desainnya untuk kepentingan masyarakat zaman sekarang. Beberapa desainer terinspirasi dari perabot kuno untuk diredesain menjadi perabot yang terkesan modern sesuai dengan gaya masa kekinian. Arsitek sekaligus desainer Robert Venturi pada tahun 1984 terinspirasi dari Queen Anne Chair (kursi Queen Anne) yang populer tahun 1720 - 1730 diredesain menjadi Queen Anne Chair gaya baru. Keberanian Robert Venturi dalam meredesain kursi Queen Anne menjadi bentuk baru menginspirasi penulis dalam meredesain Kursi Borobudur dengan konsep eklektik (Widayat, 2021).

\section{SIMPULAN}

Berdasarkan hasil dan pembahasan dapat disimpulkan bahwa jenis perabot rumah tangga meliputi yang terdapat pada relief Karmawibhangga Candi Borobudur meliputi fasiltas duduk, bantalan kasur, peti, kendi, genthong, wadah, dan peralatan profesi masyarakat kebanyakan. Kendi tempat air minum adalah jenis perabotan yang dimiliki oleh seluruh lapisan masyarakat baik kalangan rohaniawan, penguasa, maupun masyarakat kebanyakan. Kendi jenis perabot rumah tangga yang sampai saat ini masih digunakan oleh kalangan tradisional di Indonesia. Perabotan replika hasil rekonstruksi perabot rumah tangga diusahakan mendekati bentuk aslinya dari sisi bahan, dimensi, dan bentuknya. Replika ditekankan pada perabot rumah tangga yang sekarang jarang ditemukan seperti peti atau Peti Borobudur yang cukup banyak jenisnya dan penanda golongan penguasa. Manfaat rekonstruksi dan pembuatan replika jika dibuat semuanya akan dapat digunakan sebagai pengisi museum, galeri, koleksi pribadi, obyek studi dan sumber ide pengembangan desain.

\section{DAFTAR RUJUKAN}

Cahyandaru, Nahar. (2013). Cagar Budaya Candi Borobudur Sebagai Laboratorium Pendidikan. Agastya. Jurnal Sejarah dan Pembelajarannya. Vol 3, No 02 (2013): $2-20$.

Jamaludin. (2007). Pengantar Desain Mebel. Bandung: Penerbit PT Kiblat buku Utama.

Joesoef, Daoed. (2004). Borobudur. Jakarta: Penerbit Buku Kompas.

Krismono, Rachmat. 2020. Belajar Toleransi Beragama Lewat Relief Candi Borobudur. Balai Konservasi Borobudur. http://kebudayaan.kemdikbud.go.id/bkborobudur/c ategory/info-budaya/jurnal-dan-artikel-infobudaya/

Marzuki, Yasir dan Heraty, Toety. (1993). Borobudur. Jakarta: Penerbit Djambatan.

Maunah, Binti. (2015). Stratifikasi Sosial Dan Perjuangan Kelas Dalam Perspektif Sosiologi Pendidikan. TA'AlluM, Vol. 03, No. 01, Juni 2015: 19 - 38 .

Miksic, John. (1996). Borobudur Golden of the Buddhas. Singapore: Periplus Editions (HK) Ltd.

Nugrahani, D.S., (2012). Karmawibhangga: Peringatan Bagi Perilaku Manusia. Dalam Buku Adegan dan Ajaran Hukum Karma pada Relief Karmawibhangga. Magelang: Balai Konservasi Borobudur: $15-28$.

Putri, Nina Hertiwi. 2019. Kenali Rata-Rata Tinggi Orang di Indonesia dan Cara Mengukurnya. https://www.sehatq.com/artikel/tinggi-rata-ratapria-di-seluruh-dunia

Raffles, Thomas Stamford. (2008). The History of Java. Penyunting: Hamonangan Simanjuntak dan Revianto B. Santosa. Yogyakarta: Penerbit Narasi.

Santiko, Hariani. (2012). Relief Karmawibhangga di Candi Borobudur: Identifikasi Adegan dan Ajaran Hukum Karma. Dalam Buku Adegan dan Ajaran Hukum Karma pada Relief Karmawibhangga. Balai Konservasi Borobudur: 1 - 14 .

Santiko, Hariani. (2015). Toleransi Beragama dan Karakter Bangsa. Perspektif Arkeologi. Jurnal Sejarah dan Budaya 7 (1): $1-8$. 
Santiko, Hariani. (2016). Identification of Karmawibhangga Reliefs at Candi Borobudur. AMERTA, Jurnal Penelitian dan Pengembangan Arkeologi Vol. 34 No. 2, Desember 2016: 129 138.

Sidharta dan Budihardjo, Eko. (1989). Konservasi Lingkungan dan Bangunan Kuno Bersejarah di Surakarta. Yogyakarta: Gadjah Mada University Press.

Widayat, Rahmanu. (2016) Estetika Barang Kagunan Interior Dalem Ageng di Rumah Kapangéranan Keraton Surakarta, Disertasi Program Pascasarjana Institut Seni Indonesia (ISI) Surakarta.

Widayat, Rahmanu dan Studyanto, Anung B., (2017). Exploration of Design Development Borobudur Chair with The Aèng Method (strange). Proceedings of the 4th Bandung Creative Movement International Conference on Creative Industries 2017 (4th BCM 2017), Amsterdam: Atlantis Press, page $160-163$.

Widayat, R., \& Studyanto, A. B. (2021). Prototype Komersial Kursi Borobudur Menuju Hilirisasi Dengan Pendekatan Eklektik. Mudra Jurnal Seni Budaya, $\quad 36(1), \quad 15-22$. https://doi.org/10.31091/mudra.v36i1.1313

Yatno, Tri. (2020). Candi Borobudur Sebagai Fenomena Sakral Profan: Agama dan Pariwisata Perspektif Strukturalisme Levi Strauss. Sabbhata Yatra Jurnal Pariwisata dan Budaya, Volume 1 Nomor 1 Juli 2020: 1 - 14.

\section{WEBTOGRAFI}

Badan Pusat Satistik, 2021.

(https://www.bps.go.id/istilah/index.html?Istilah\%5 Bberawalan\%5D $=$ R\&Istilah_page $=4$ diunduh 20 Juni 2021)

Balai Pelestarian Cagar Budaya (BPCB) Jawa Tengah, 2019.

(https://kebudayaan.kemdikbud.go.id/bpcbjateng/si lpin-dan-citralekha-siapa-mereka/ diunduh 27 Juni 2021)

King Tut Replica Throne Chair, 2021

(https://www.liveauctioneers.com/item/59496708

king-tut-replica-throne-chair diunduh 27 Juni 2021) 